Retraction

\title{
Retraction: HCRP-1 regulates cell migration, invasion and angiogenesis via Src/ FAK signaling in human prostate cancer
}

International Journal of Biological Sciences

(C) Ivyspring International Publisher. This is an open access article distributed under the terms of the Creative Commons Attribution License (https://creativecommons.org/licenses/by/4.0/). See http://ivyspring.com/terms for full terms and conditions.

Published: 2021.11.10

Corrected article: Int J Biol Sci 2020; 16(2): 342-352. doi: 10.7150/ijbs.38112.

The article (Chen F, Wu J, Teng J, Li W, Zheng J, Bai J. HCRP-1 regulates cell migration, invasion and angiogenesis via Src/ FAK signaling in human prostate cancer. Int J Biol Sci 2020; 16(2):342-352. doi:10.7150/ijbs.38112) has been retracted due to concerns on multiple image duplications as identified by PubPeer users. This raises concerns about the integrity of the data presented in the paper. 